\title{
Building Bonds, Healing Youth: Prioritizing Youth Critical Consciousness Development in CBPR
}

\author{
Briana Woods-Jaeger, ${ }^{1}$ Paige O'Connor ${ }^{2}$, Teesha Miller ${ }^{2}$, Chakilah Wade ${ }^{2}, D^{\prime}$ Marko Price ${ }^{2}$, Briana Boykin', Kelsey Christensen ${ }^{3}$, \\ Jannette Berkley-Patton ${ }^{3}$ \\ ${ }^{1}$ Rollins School of Public Health, Emory University (GA), ${ }^{2}$ Youth Ambassadors, ${ }^{3}$ University of Missouri \\ Keywords: violence exposure, resilience, youth development \\ https://doi.org/10.35844/001c.13271
}

\section{Journal of Participatory Research Methods}

\begin{abstract}
Community violence continues to be a major national public health issue that disproportionately impacts African American youth. Community Based Participatory Research (CBPR) approaches have been recommended to address youth violence and provide an opportunity to partner in research with those most impacted to develop new strategies. In this brief report we describe specific capacity building efforts in our CBPR project, Building Bonds, Healing Youth, which aims to develop and test a community-level intervention to promote resilience among African American youth exposed to community violence. We specifically describe our capacity building efforts that centered around developing youth critical consciousness and highlight specific methods that we employed. Reflections from our youth partners highlight the potential impact of incorporating youth critical consciousness development into capacity building efforts with youth partners. This brief report supports incorporating critical consciousness in CBPR with youth to promote mutual benefit as youth contribute their lived experiences, expertise, and commitment to improving research addressing youth health and well-being.
\end{abstract}

\section{Introduction}

Community violence is a major public health issue that disproportionately impacts African American (AA) youth. AA youth are more likely to be exposed to ongoing community violence than White youth (Centers for Disease Control and Prevention, 2009; Morgan \& Truman, 2019) and experience a myriad of related health and well-being issues (e.g., sleep disruption, sexual risks, depression, isolation, and academic failure) (Busby et al., 2013; Kliewer et al., 2019; Voisin et al., 2016). Few interventions specifically target community violence exposure (Voisin \& Berringer, 2015), particularly among AA youth. New strategies are necessary to address the needs of AA youth burdened with the consequences of community violence.

Community-Based Participatory Research (CBPR) emphasizes community-developed research agendas, shared decision making, co-learning, and local capacity building to understand and intervene in problems from a socioecological perspective (Frerichs et al., 2016; Israel et al., 1998; Wallerstein $\&$ Duran, 2006). Increasingly, CBPR approaches are recommended to address youth violence (David-Ferdon \& Simon, 2014) and provide an opportunity to partner with those most impacted to address public health gaps and build community capacity in the process (Collins et al., 2018). In this brief report, we describe capacity-building efforts in our CBPR project (Building Bonds, Healing Youth), which aims to develop and test a community-level intervention to promote resilience among AA youth exposed to community violence. Our 
Table 1. Application of Youth Critical Consciousness Strategies in CBPR

\begin{tabular}{|c|c|c|c|}
\hline & Critical Reflection & Political Efficacy & Social Action \\
\hline \multirow[t]{4}{*}{ Strategies } & $\begin{array}{l}\text { Engage in critical dialogue at CAB } \\
\text { meetings on research process and } \\
\text { findings with attention to youth lived } \\
\text { experience with community violence } \\
\text { and resilience }\end{array}$ & Have a leadership role on the CAB & $\begin{array}{l}\text { Partner with community } \\
\text { leaders and entities with power } \\
\text { to translate research to action }\end{array}$ \\
\hline & $\begin{array}{l}\text { Expand understanding of and } \\
\text { critically reflect on social and } \\
\text { community issues in problem } \\
\text { identification process }\end{array}$ & $\begin{array}{l}\text { Serve as decision makers in } \\
\text { research implementation }\end{array}$ & $\begin{array}{l}\text { Challenge adults to value and } \\
\text { use youths' lived experiences } \\
\text { when considering how to } \\
\text { address community violence } \\
\text { and youth resilience }\end{array}$ \\
\hline & $\begin{array}{l}\text { Participate in designing data } \\
\text { collection tools (e.g., resilience needs } \\
\text { assessment), and reviewing and } \\
\text { interpreting data (e.g., focus groups) }\end{array}$ & $\begin{array}{l}\text { Plan and implement community } \\
\text { forums to promote critical } \\
\text { dialogue about research findings } \\
\text { among community stakeholders }\end{array}$ & $\begin{array}{l}\text { Develop solutions and } \\
\text { influence policies based on } \\
\text { research data, community, and } \\
\text { youth perspectives }\end{array}$ \\
\hline & $\begin{array}{l}\text { Determine priority resilience and } \\
\text { trauma-related issues to address }\end{array}$ & $\begin{array}{l}\text { Provide feedback on each stage of } \\
\text { the research process, including } \\
\text { decision-making on recruitment, } \\
\text { research program components, } \\
\text { and outcomes }\end{array}$ & $\begin{array}{l}\text { Mobilize relevant community } \\
\text { sectors to assist in providing } \\
\text { support and enhancing youth } \\
\text { resilience with youth-engaged } \\
\text { programs }\end{array}$ \\
\hline
\end{tabular}

capacity-building efforts centered around developing critical consciousness (CC), particularly among our youth partners, and were facilitated through our community advisory board ( $\mathrm{CAB})$. During our first two years, three specific $\mathrm{CAB}$ activities aimed to promote youth $\mathrm{CC}: 1)$ focus group data interpretation; 2) resilience needs assessment survey development; and 3) community forum planning and implementation. We describe each of these activities, how we focused on youth CC development, and share our lessons learned.

\section{Emphasizing Youth Critical Consciousness Development in our CBPR Process}

Critical consciousness (CC) has been defined in many ways, but generally includes critical reflection, political efficacy, and social action (Watts et al., 2011). It requires prioritizing participation, leadership, social networks, and power (Goodman et al., 1998) to build the foundation for sustainable work (Frerichs et al., 2016). The benefits of CC among youth are well-documented and include promoting mental health (Zimmerman et al., 1999), career development (Diemer et al., 2010), and occupational attainment in adulthood (Diemer, 2009). CBPR, with a foundation in critical theory, provides an opportunity for researchers and community partners to heighten critical consciousness (Branom, 2012). Engaging youth in participatory research through problem identification, analyzing and interpreting data, and providing feedback at every stage of research promotes critical consciousness (Foster-Fishman et al., 2010).

\section{Youth Ambassadors Partnership}

Youth Ambassadors (YA), established in 2010, serves over 250 underserved teenagers (ages 14-18) annually from the Kansas City, Missouri, metropolitan area. A substantial portion of YA teenagers are $\mathrm{AA}$, have a history of multiple trauma exposure, and live in environments of concentrated poverty. YA uses 
a strength-based curriculum that fosters resiliency by strengthening intrapersonal and interpersonal competence to mitigate the negative consequences of concentrated poverty and trauma exposure. Academic partners had previously collaborated with YA by volunteering at YA-sponsored career fairs and implementing a policy advocacy curriculum during the YA summer program. Through these experiences, a relationship was developed that led YA and academic partners to jointly pursue a funding opportunity to address youth violence and resilience. As a trusted youth development organization in the community, YA facilitated the engagement of youth partners in the Building Bonds, Healing Youth project. YA viewed promoting youth engagement in the CBPR project as an extension of their mission to increase opportunities for youth to thrive and advocate for change.

\section{CBPR Activities to Promote Youth Critical Consciousness}

\section{Building Bonds Community Action Board (CAB)}

The Building Bonds $\mathrm{CAB}$ consisted of YA members, academic partners, and youth-serving adults from organizations representing multiple community sectors, who partnered to design and test a community-level resilience intervention. The Building Bonds $\mathrm{CAB}$ was guided by the recognition that to develop relevant and sustainable reliance-enhancing solutions in the face of community violence exposure, youth must be at the table. As one of our youth $C A B$ leaders stated, "The only way to reach youth is to involve youth in the decision-making process.” Building Bonds $\mathrm{CAB}$ meetings were structured to create a space for critical reflection and discussion regarding the research process and findings. Critical reflections often extended to youth's own lived experiences. As one youth $\mathrm{CAB}$ member described, "I always grew up around violence, so in order to survive I felt I needed to be violent. The first meeting with Building Bonds showed me that there was possibly a way to survive without having to succumb to violence." The critical reflection and discussion that occurred during $\mathrm{CAB}$ meetings provided mutual benefit in the CBPR process - enhancing the relevance of the research and honoring youths' lived experiences. One youth $\mathrm{CAB}$ member shared, "I always felt invisible in my family, because everyone assumed I was okay. I was fine in school, and I never caused problems, but I wasn't okay, because in my home I witnessed domestic violence every day. The $\mathrm{CAB}$ acknowledged me and provided me with a chance to be understood." The development of CC has been associated with healing processes for youth who have experienced violence (Ginwright, 2010), and it was critical to make space for this in our CBPR process. We learned that it was helpful to share information via a $\mathrm{CAB}$ newsletter and solicit feedback via email or phone between $\mathrm{CAB}$ meetings to allow more time for critical dialogue during each meeting.

\section{Focus Group Data Interpretation}

We conducted five focus groups with thirty-nine urban AA youth exposed to community violence to inform the development of our Building Bonds community-level resilience intervention. During two $\mathrm{CAB}$ meetings and one 
community forum planning meeting, youth $\mathrm{CAB}$ members participated in an extensive "member-checking" process that involved reviewing focus group data and ensuring appropriate data interpretations. During these meetings, researchers described preliminary focus group themes and passed out printed youth quotes that reflected each theme to facilitate ample discussion about the quotes. Through this process, youth leaders appeared to develop CC as they discussed social, economic, and political conditions that perpetuate community violence, refined data interpretations, and identified additional areas to further examine. As one youth leader stated, "We just really wanted each person to take each quote and be able to relate to it on a personal stance."

Youth refined the data interpretation regarding the preliminary themes. For example, for the theme of inadequate responses from law enforcement, youth indicated that while current law enforcement responses were inadequate and led to feelings of mistrust, youth desired to have a closer relationship with law enforcement and saw them as critical in promoting community safety. Presenting this balanced interpretation of the data was important to youth. Youth also identified areas for further study, such as barriers to getting family support as critical to examine. This barrier was not an original an aim of the study, which was focused more on community-level factors. This feedback informed the resilience needs assessment and priorities for social action. We learned that it is critical that the member-checking process allows for ample time to conduct data interpretation and to engage in critical dialogue regarding what is missing from the data and needs to be further examined.

\section{Resilience Needs Assessment (RNA) Survey Development}

Needs assessments have traditionally been used to identify priority areas of focus to address a community-identified problem (Berkley-Patton et al., 2018; Fawcett et al., 1988). Guided by areas identified in our focus group memberchecking process, the research team prepared an initial draft of a community RNA survey. The RNA survey draft included items on demographics, health behaviors, psychosocial measures, and multi-sectoral strategies that had the potential to enhance resilience with urban AA youth exposed to community violence. Two $\mathrm{CAB}$ meetings were used to review draft survey items and refine the survey. During these meetings, several questions were removed that youth did not believe were relevant to their peers, some questions were added, and several questions were modified to improve readability. Youth expressed concerns that most of the behavioral and psychosocial items were being posed to youth and not adults, and felt it was important to know about the experiences of the adults who served them. They were also concerned that these important questions were at the end of the survey and that youth may not complete them due to the survey length. Based on this feedback, the adult version of the survey was expanded to include behavioral and psychosocial items, questions were reordered, and the youth survey was shortened to reduce survey fatigue. 
The final surveys were administered with 189 urban youth and 97 adults who serve youth in key community sectors. Survey findings were discussed during $\mathrm{CAB}$ meetings. This process of survey development provided an opportunity for youth $\mathrm{CAB}$ members to build political efficacy. As one youth leader shared, "I didn't know how much community violence affects the larger community... It motivated me and inspired me to do better. I know what it's like to grow up in violence and have no one to talk to. It's a struggle and it can bring you down - mentally and physically. I want to make a place where they can share their experience and figure out a way to make the problem better." Our youth-engaged RNA survey development process highlights the value in incorporating specific feedback from youth and engaging in critical dialogue on why and how the survey can benefit the community.

\section{Youth Community Forum}

The Building Bonds community forum provided an opportunity for youth $\mathrm{CAB}$ members to extend their development of $\mathrm{CC}$ to the larger community through promoting community critical reflection and dialogue around the focus group and RNA findings to inform social action. A forum planning committee, comprised of youth $\mathrm{CAB}$ members and core research team members, met regularly via in-person meetings, GroupMe messages, and phone calls. Forum planning activities included: identifying forum goals; selecting data to share at the forum; determining the format for attendee participation; identifying community stakeholders to invite; and developing advocacy priorities to further develop CC among youth partners. The planning process further nurtured youths' political efficacy as their social networks expanded and supported their ability to carry out their vision as leaders. One youth CAB member shared: "Supporting each other is the only way we are going to affect change. Giving a platform where youth together can address an issue provides a first step in healing."

Providing opportunities for leadership in the implementation of the community forum was also critical to nurturing youth CC. During the forum, youth introduced the mayor as the keynote speaker, shared their peers' writings on experiences of community violence, and co-facilitated table discussions which engaged forum attendees in critical reflection on study findings and priorities for social action. We learned the importance of involving youth and promoting youth leadership roles in every detail of the planning process.

\section{Conclusion}

Building Bonds, Healing Youth aimed to develop and test a community-level intervention to promote resilience among African American youth exposed to community violence. Each phase centered on youth CC development as a priority. Lessons learned support the feasibility of prioritizing youth CC development in CBPR and reflections from our youth partners support its importance. One of our youth $\mathrm{CAB}$ leaders summarized her experience, stating, "It made me realize that everyone has their own challenges and how strong youth are. Despite what we have all been through they are still so strong. 
We have to make a change and the community needs to know what the youth go through." We hope others will prioritize CC when partnering with youth in CBPR to promote mutual benefit and capacity building. 


\section{References}

Berkley-Patton, J., Thompson, C. B., Bradley-Ewing, A., Berman, M., Bauer, A., Catley, D., Goggin, K., Williams, E., Wainright, C., Petty, T., \& Aduloju-Ajijola, N. (2018). Identifying health conditions, priorities, and relevant multilevel health promotion intervention strategies in African American churches: A faith community health needs assessment. Evaluation and Program Planning, 67, 19-28. https://doi.org/10.1016/j.evalprogplan.2017.10.012

Branom, C. (2012). Community-based participatory research as a social work research and intervention approach. Journal of Community Practice, 20(3), 260-273. https://doi.org/10.1080/ $\underline{10705422.2012 .69987}$

Busby, D. R., Lambert, S. F., \& Ialongo, N. S. (2013). Psychological symptoms linking exposure to community violence and academic functioning in African American adolescents. Journal of Youth and Adolescence, 42(2), 250-262. https://doi.org/10.1007/s10964-012-9895-z

Centers for Disease Control and Prevention. (2009). Selected health risk behaviors and health outcomes by race/ethnicity -National YRBS. [PDF file]. http://www.cdc.gov/HealthyYouth/yrbs/pdf/ us_disparityrace_yrbs.pdf

Collins, S. E., Clifasefi, S. L., Stanton, J., The LEAP Advisory Board, Straits, K. J. E., GilKashiwabara, E., Rodriguez Espinosa, P., Nicasio, A. V., Andrasik, M. P., Hawes, S. M., Miller, K. A., Nelson, L. A., Orfaly, V. E., Duran, B. M., \& Wallerstein, N. (2018). Community-based participatory research (CBPR): Towards equitable involvement of community in psychology research. American Psychologist, 73(7), 884-898. https://doi.org/10.1037/amp0000167

David-Ferdon, C., \& Simon, T. R. (2014). Preventing Youth Violence: Opportunities for Action. [PDF file]. Centers for Disease Control and Prevention. https://www.cdc.gov/violenceprevention/ youthviolence/pdf/opportunities-for-action.pdf

Diemer, M. A. (2009). Pathways to occupational attainment among poor youth of color: The role of sociopolitical development. The Counseling Psychologist, 37(1), 6-35. https://doi.org/10.1177/ $\underline{0011000007309858}$

Diemer, M. A., Wang, Q., Moore, T., Gregory, S. R., Hatcher, K. M., \& Voight, A. M. (2010). Sociopolitical development, work salience, and vocational expectations among low socioeconomic status African American, Latin American, and Asian American youth. Developmental Psychology, 46(3), 619-635. https://doi.org/10.1037/a0017049

Fawcett, S. B., Suarez de Balcazar, Y., Whang-Ramos, P. L., Seekins, T., Bradford, B., \& Mathews, R. M. (1988). The concerns report: Involving consumers in planning for rehabilitation and independent living services. American Rebabilitation, 14(3), 17-19.

Foster-Fishman, P. G., Law, K. M., Lichty, L. F., \& Aoun, C. (2010). Youth ReACT for social change: A method for youth participatory action research. American Journal of Community Psychology, 46(1-2), 67-83. https://doi.org/10.1007/s10464-010-9316-y

Frerichs, L., Lich, K. H., Dave, G., \& Corbie-Smith, G. (2016). Integrating systems science and community-based participatory research to achieve health equity. American Journal of Public Health, 106(2), 215-222. https://doi.org/10.2105/ajph.2015.302944

Ginwright, S. A. (2010). Peace out to revolution! Activism among African American youth: An argument for radical healing. Young, 18(1), 77-96. https://doi.org/10.1177/110330880901800106

Goodman, R. M., Speers, M. A., McLeroy, K., Fawcett, S., Kegler, M., Parker, E., Smith, S. R., Sterling, T. D., \& Wallerstein, N. (1998). Identifying and defining the dimensions of community capacity to provide a basis for measurement. Health Education $\xi^{2}$ Behavior, 25(3), 258-278. https://doi.org/10.1177/109019819802500303 
Israel, B. A., Schulz, A. J., Parker, E. A., \& Becker, A. B. (1998). Review of community-based research: Assessing partnership approaches to improve public health. Annual Review of Public Health, 19(1), 173-202. https://doi.org/10.1146/annurev.publichealth.19.1.173

Kliewer, W., Robins, J. L., \& Borre, A. (2019). Community violence exposure, sleep disruption, and insulin resistance in low-income urban adolescents. International Journal of Behavioral Medicine, 26(4), 437-442. https://doi.org/10.1007/s12529-019-09801-7

Morgan, R. E., \& Truman, J. L. (2019). Criminal victimization, 2017. [PDF file]. National Crime Victimization Survey, Bureau of Justice Statistics. https://bjs.gov/content/pub/pdf/cv17.pdf

Voisin, D. R., \& Berringer, K. R. (2015). Interventions targeting exposure to community violence sequelae among youth: A commentary. Clinical Social Work Journal, 43(1), 98-108. https://doi.org/10.1007/s10615-014-0506-1

Voisin, D. R., Patel, S., Hong, J. S., Takahashi, L., \& Gaylord-Harden, N. (2016). Behavioral health correlates of exposure to community violence among African-American adolescents in Chicago. Children and Youth Services Review, 69, 97-105. https://doi.org/10.1016/ j.childyouth.2016.08.006

Wallerstein, N. B., \& Duran, B. (2006). Using community-based participatory research to address health disparities. Health Promotion Practice, 7(3), 312-323. https://doi.org/10.1177/ $\underline{1524839906289376}$

Watts, R. J., Diemer, M. A., \& Voight, A. M. (2011). Critical consciousness: Current status and future directions. New Directions for Child and Adolescent Development, 2011(134), 43-57. https://doi.org/10.1002/cd.310

Zimmerman, M. A., Ramírez-Valles, J., \& Maton, K. I. (1999). Resilience among urban African American male adolescents: A study of the protective effects of sociopolitical control on their mental health. American Journal of Community Psychology, 27(6), 733-751. https://doi.org/ 10.1023/a: 1022205008237 